\title{
Inhalation Dosing Unit
}

National Cancer Institute

\section{Source}

National Cancer Institute. Inhalation Dosing Unit. NCI Thesaurus. Code C48501.

A dosing unit equal to the amount of active ing redient(s) contained in an inhalation. 